\title{
Basal rot of Chamelaucium uncinatum caused by Phytophthora nicotianae in Argentina
}

\author{
H. E. Palmucci • P. E. Grijalba • S. M. Wolcan
}

Received: 6 September 2011 / Accepted: 18 January 2013 /Published online: 2 February 2013

(C) Australasian Plant Pathology Society Inc. 2013

\begin{abstract}
Since 1995 severe losses were recorded on the production of Chamelaucium uncinatum in the vicinity of La Plata. In 2010, with the aim to confirm the identity of the causal agent of Geraldton waxplant basal rot, molecular studies were added to the morphological observations of the pathogen. $P$. nicotianae was identified as the causal agent of the disease.
\end{abstract}

Keywords Chamelaucium uncinatum $\cdot$ Phytophthora nicotianae $\cdot$ Basal rot · Oomycetes

Geraldton waxplant (Chamelaucium uncinatum Schauer.) is a shrub belonging to the Myrtaceae family that is native to Australia. It was introduced into Argentina (Buenos Aires Province) in the 1990 s and is mainly cultivated in the outskirts of La Plata $\left(34^{\circ} 55^{\prime} \mathrm{S}, 57^{\circ} 57^{\prime} \mathrm{W}\right)$. Plants are grown in greenhouses and are mainly used as flowering branches in bouquets and also as potted plants. Since 1995, severe losses have been recorded in plants at different stages of growth. Plants showed progressive yellowing of the branches from the base to the top of the stems. Leaves of diseased plants became greyish green, then yellow, and finally straw coloured. Leaves remained attached to the branches after the plants died (Fig. $1 a$ and $b$ ). Roots and stem discolouration

H. E. Palmucci $(\bowtie) \cdot$ P. E. Grijalba

Facultad de Agronomía de la Universidad Nacional de Buenos

Aires, UBA, 1416 Buenos Aires, Argentina

e-mail: palmucci@agro.uba.ar

S. M. Wolcan

CIC-CIDEFI, Facultad de Ciencias Agrarias y Forestales, UNLP,

Buenos Aires, Argentina was observed and the root cortex sloughed off. Based on morphological characteristics of early isolates cultivated on potato dextrose agar (PDA), the pathogen was identified as Phytophthora boehmeriae Sawada (Wolcan and Lori 2001).

In 2004, 22 isolates of Phytophthora were obtained from stem bases and roots from plants of different ages showing symptoms described above. These diseased plants were collected from 11 greenhouses from different farmers located in the same cropping area. Koch's postulates were fulfilled and the pathogen was identified by morphological and cultural characteristics on PDA as Phytophthora nicotianae Breda de Haan (Wolcan et al. 2005, unpublished).

In 2010, in order to confirm the identity of the causal agent of Geraldton waxplant basal rot in the vicinity of $\mathrm{La}$ Plata, molecular studies were added to the morphological observations of the pathogen. Plants were collected from the same location. Small sections of diseased tissue from 10 plants were washed and placed directly on PDA and vegetable juice agar (V8A), both containing pimaricin-ampicilinrifampicin-pentachloronitrobenzene-hymexazol (PARPH) and incubated at 23 to $25{ }^{\circ} \mathrm{C}$. Pure cultures were obtained by single-hypha transfers after 2 to 3 days to PDA and V8A. After 5 to 7 days, fifteen colonies with cultural and morphological features of a Peronosporomycete developed. Routine isolations on PDA were also carried out. Pathogenicity tests were performed with the isolate BFCH110 that was characterized morphologically and molecularly.

The isolates formed white, stoloniferous colonies on PDA (Fig. 2) with characteristic coralloid mycelia and grew between $8{ }^{\circ} \mathrm{C}$ and $36{ }^{\circ} \mathrm{C}$, with an optimum of $28^{\circ} \mathrm{C}$. They produced persistent, mono- and sometimes bipapillate, spherical to ovoid, ellipsoid, obpyriform sporangia (Fig. $3 a$ and $b$ ) (28-54×42-46 $\mu \mathrm{m}$; length/breadth ratio of $1.3: 1)$. Terminal 

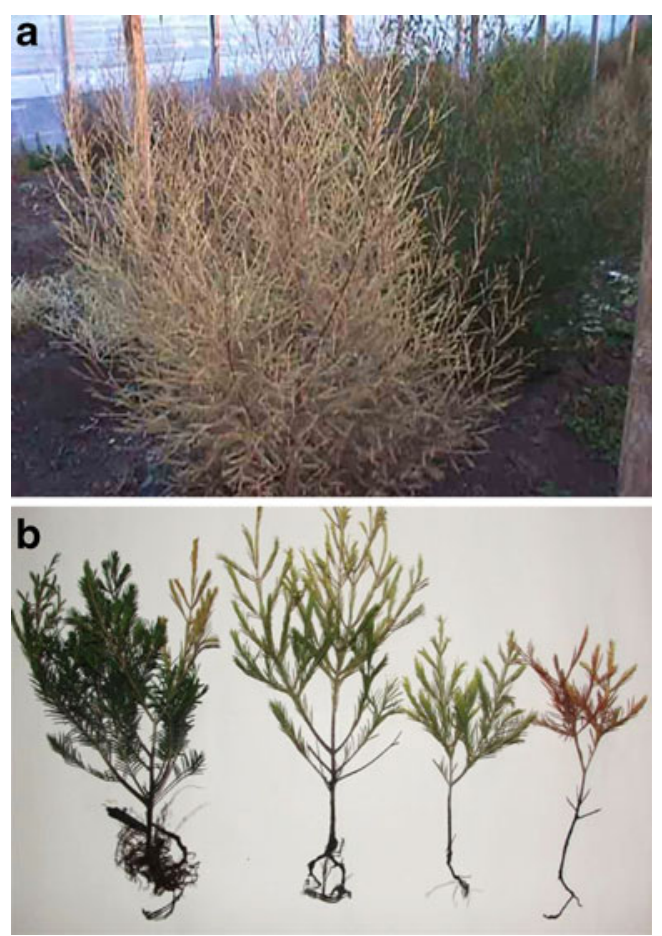

Fig. 1 Symptoms: a Disease plant in the greenhouse. b Progress of symptoms in young plants

and intercalary chlamydospores ( 25 to $48 \mu \mathrm{m}$ in diameter; average $37 \mu \mathrm{m}$ ) and hyphal swellings were also present. Sexual structures were not observed. Morphological and cultural characteristics agreed with P. nicotianae.

The complete internal transcribed spacer (ITS) region of rDNA was amplified with primers ITS5 (3'-GGAAGTAA AAGTCGTAACAAGG-5') and ITS4 (5'-TCCTCCG CTTATTGATATGC-3') (White et al. 1990) and directly sequenced. DNA was extracted following Lyse-n-Gotm protocol. A small amount of mycelium was picked with the tip of a toothpick and placed in $30 \mathrm{ml}$ of Lyse-n-Gotm buffer and incubated twice under the following conditions: $2 \mathrm{~min}$

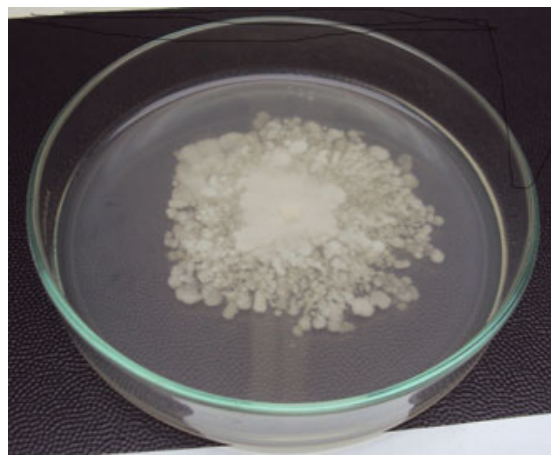

Fig. 2 Stoloniferous colony growing on potato dextrose agar (PDA)
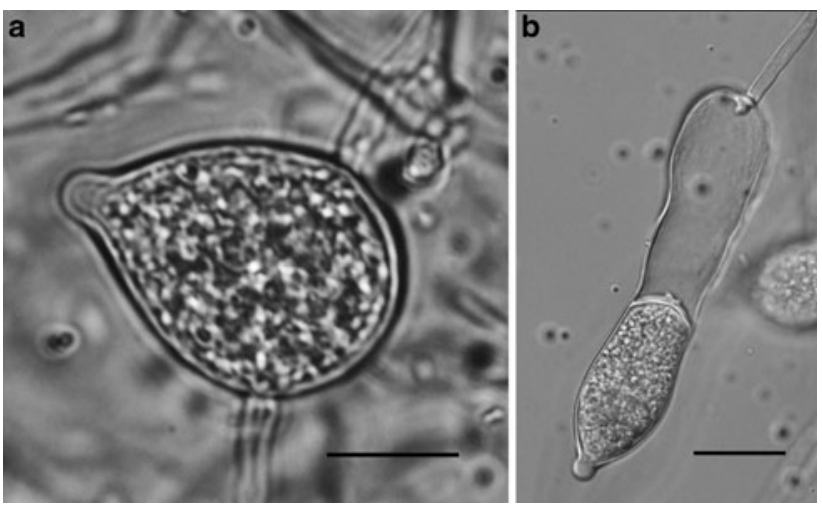

Fig. 3 a Intercalary papillate sporangium, bar $=20 \mu \mathrm{m}$. b Irregular shaped, semi empty sporangium, bar $=30 \mu \mathrm{m}$

at $95^{\circ} \mathrm{C}$ and 2 min at $4{ }^{\circ} \mathrm{C}$, twice. DNA was amplified by PCR in a total volume of $19 \mathrm{ml}$. Primers at $0.05 \mathrm{mM}$ concentration were used with the Pt Taq polymerase and $0.5 \mathrm{mM}$ of deoxyribonucleotide triphosphate (dNTP's). PCR tubes were placed in the thermal cycler with the following temperature profile: 1 cycle $1 \min 25 \mathrm{~s}$ at $94^{\circ} \mathrm{C} ; 35$ cycles $35 \mathrm{~s}$ denaturation at $93^{\circ}$ C, $30 \mathrm{~s}$ annealing at $52{ }^{\circ} \mathrm{C}, 1 \mathrm{~min}$ extension at $72{ }^{\circ} \mathrm{C}$; with a final extension of $10 \mathrm{~min}$ at $72{ }^{\circ} \mathrm{C}$. Visual quantification was made by comparison with a DNA low mass ladder (Invitrogen, Carlsbad, CA) following electrophoresis on $1 \%$ agarose gel and stained with ethidium bromide. In order to minimize sequencing errors, both chains $5^{\prime}$ to $3^{\prime}$ as well as $3^{\prime}$ to $5^{\prime}$ were obtained. The consensus sequences or contigs were assembled using the GeneTool Life 1.0 program (Layon 2000) and any possible ambiguities were resolved.

The identity of the amplified fragments was determined by sequence alignment with published sequences from Genebank, using the Basic Local Alignment Search Tool (BLAST) program (Altschul et al. 1997).

Two ITS sequences of P. boehmeriae [Acc. \# AY428533 and DQ297406- Dos Santos et al. 2006], two reliable sequences of P. nicotianae [AF266776 (neotype) and AY423299] and the sequence obtained in this study were aligned using the Clustal W program. Our sequence has $100 \%$ agreement with the identity of known $P$. nicotianae. Results were validated against morphometric and literature data. The resulting sequence was deposited in GenBank (Accession \# JN160803).

A phylogenetic tree was constructed with the MEGA program version 5.0, using the Neighbor-joining method with 1000 bootstrap replications (Fig. 4). The sequence obtained in this study (GenBank JN160803) aligned well with the two ITS sequences of $P$. nicotianae and formed a phylogenetic clade with two ITS sequences of $P$. boehmeriae.

Koch's postulates were fulfilled in a greenhouse at 27 to $34{ }^{\circ} \mathrm{C}$ using the Snowflake and Orchid cultivars. Inoculum was obtained by growing the fungus for 10 days in Petri dishes 
Fig. 4 Phylogenetic tree using rDNA ITS sequences showing the relationship between isolates from Phytophthora nicotianae and $P$. boehmeriae

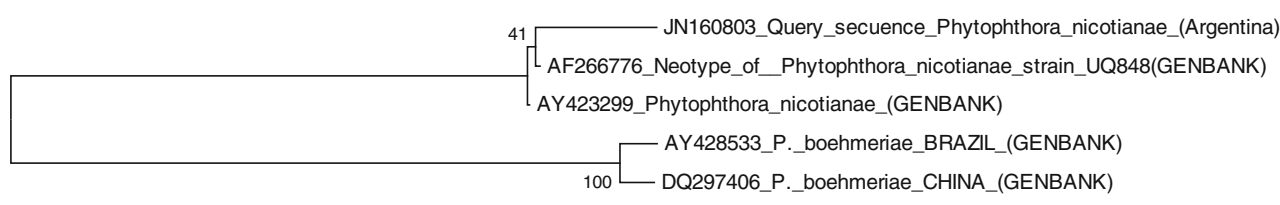

0.02

containing an autoclaved wet mixture of polished rice + wheat bran + V8 juice + perlite $(1: 1: 1: 1, v / v)$. The inoculum was mixed with soil $(4: 100, v / v)$ in pots, and ten 4-month-old plants per cultivar were transplanted into infested soil. Ten plants were not treated and served as controls. Pots were flooded during the first $48 \mathrm{~h}$. Symptoms began 25 days after inoculation in plants of cv. Snowflake. At the end of the trial (4 months) $70 \%$ of these plants had died. Disease development was delayed on plants of cv. Orchid and low mortality was observed. Control plants remained healthy. P. nicotianae was re-isolated from symptomatic plants. The isolate was deposited in the culture collections of the FAUBA and CIDEFI with the accession number BFCH110 for both collections.

P. nicotianae, $P$. citricola, P. cryptogea, $P$. drechsleri and $P$. cinnamommi have been reported on $C$. uncinatum in Australia (Shivas 1989).

The first isolates from C. uncinatum that were opportunely identified as $P$. boehmeriae were lost due to the contamination of the stock cultures. Therefore, the accurate molecular identification is not possible at present. Isolates obtained in the following years were identified as $P$. nicotianae using morphological and molecular techniques. On the other hand, $P$. bohemeriae has never been identified again in the region, nor has it been reported on C. uncinatum elsewhere. P.nicotianae was isolated from several crops in the same floricultural area (Rivera et al. 2000; Wolcan et al. 2007; Palmucci et al. 2011) and besides it was reported on C. uncinatum (Shivas 1989). Due to this, it might be considered that there had been a misidentification and $P$. nicotianae would be the only Phytophthora species affecting C. uncinatum in Argentina.

The first isolates could have been homothallic strains of $P$. nicotianae while the other isolates studied later were heterothallic.
This is the first confirmed report of P. nicotianae on $C$. uncinatum in Argentina and it appears to be the second one in the world.

Acknowledgments Authors would like to thanks Dr Z. Gloria Abad (Center of Plant Health Science and Technology CPHST) for sharing with us her extensive knowledge.

\section{References}

Altschul SF, Madden TL, Schäffer AA, Zhang GJ, Zhang Z, Miller W, Lipman DJ (1997) Gapped BLAST and PSI-BLAST: a new generation of protein database search programs. Nucleic Acid Res 25:389-402

Dos Santos AF, Luz EDMN, De Souza JT (2006) First report of Phytophthora boehmeriae on black wattle in Brazil. New Disease Reports: 13, 23. In: http://www.ndrs.org.uk/article.php?id=013023

Layon M (2000) GeneTool 1.0. Biotech Softw and Internet Rep 1:261-264

Palmucci HE, Grijalba PE, Wolcan SM, Guillin E, López MV, Herrera C, Fantino E (2011) Phytophthora nicotianae causing root and stem rot on Dieffenbachia picta in Argentina. Trop Plant Pathol 36:327-331

Rivera MC, Delfino OSF, Wright ER, Rivera González A (2000) Respuesta de cultivares de Catharanthus roseus frente a Phytophthora parasitica. Hortic Argent 19:52-57

Shivas RG (1989) Fungal and bacterial diseases of plants in Western Australia. J Roy Soc W Aust 72:1-62

White TJ, Bruns T, Lee S, Taylor J (1990) Amplification and direct sequencing of fungal ribosomal RNA genes for phylogenetics. 315-322. In: Innis MA, Gelfand DH, Sninsky JJ, White TJ (eds) PCR-Protocols. A Guide to methods and applications. Academic Press, Inc, New York

Wolcan SM, Lori GA (2001) Basal rot of geraldton waxplant caused by Phytophthora boehmeriae. Plant Dis 85:98

Wolcan S, Ronco L, Lori G (2007) Podredumbres basales de Gypsophila paniculata (Caryophylaceae) en la Argentina. Agentes causales y su patogenicidad potencial sobre Dianthus caryophyllus (Caryophylaceae). Bol Soc Bot Argent 42:159-167 